\title{
Aspergillus leaf spot of field bindweed (Convolvulus arvensis L.) caused by Aspergillus niger in China
}

\author{
Xuekun Zhang ${ }^{1 *} \mathbb{D}$, Hui Xi ${ }^{2}$, Kejian Lin' ${ }^{1}$ Z Zheng Liu' ${ }^{1}$ Yu Yu ${ }^{1}$, Yan Sun ${ }^{1}$ and Jing Zhao ${ }^{1}$
}

\begin{abstract}
Leaf spot was found on field bindweed (Convolvulus arvensis L.) in Shihezi City, Xinjiang Province, China, during the summer of 2015. Pathogens were isolated from the infected leaves of field bindweed and identified as Aspergillus niger based on morphological and molecular analyses (internal transcribed spacer rDNA and $\beta$-tubulin gene). A pathogenicity test confirmed that Aspergillus niger caused the healthy leaves of field bindweed to become diseased. To our knowledge, this is the first report of field bindweed infected naturally by A. niger.
\end{abstract}

Keywords: Leaf spot, Field bindweed, Internal transcribed spacer rDNA, $\beta$-Tubulin gene, Aspergillus niger

\section{Background}

Field bindweed is a global malignant perennial weed (Vasilakoglou et al. 2013), which competes with many crops, including corn, wheat, beans, cotton, and vegetables, for water, inorganic salt, nutrients, and light (Rodríguez-Navarro et al. 2011; Vasilakoglou et al. 2013). The qualities and yields of the crops declined in areas where field bindweed occurred (Lindenmayer et al. 2013). Field bindweed has become one of the most serious weed problems in Xinjiang, majorly affecting the growth of cotton and lacking effective methods to control it currently (Ma et al. 2010).

Field bindweed has a natural resistance to chemical herbicides; therefore, conventional herbicides are generally ineffective for its control (Westwood and Weller 1997). Since 1979, plant pathogens have been used as weed management because they were relatively safe and did not result in herbicide resistance (Charudattan and Walker 1982; Aneja et al. 2013). Field bindweed could be naturally infected by Alternaria triticina and Phomopsis

\footnotetext{
*Correspondence: 309448566@qq.com

${ }^{1}$ Northwest Inland Region Key Laboratory of Cotton Biology and Genetic Breeding (Xinjiang), Ministry of Agriculture, Institute of Plant Protection, Xinjiang Academy Agricultural and Reclamation Sciences,

No. 221 Wuyi Road, Shihezi, China

Full list of author information is available at the end of the article
}

longicolla (Saleem et al. 2015; Li et al. 2010). During the summer of 2015, naturally diseased leaves of field bindweed were collected in Shihezi City. The aims of the present study were to identify the species isolated from field bindweed by using morphological and molecular analyses and provide potential biocontrol resources for field bindweed.

\section{Methods \\ Isolation and cultivation of the pathogen}

Field bindweed leaves $\left(2 \times 6 \mathrm{~mm}^{2}\right)$ were selected at the junction of diseased and healthy tissues. The surface of the selected leaves were sterilized with $0.1 \% \mathrm{HgCl}_{2}$ for $45 \mathrm{~s}$ and rinsed in sterile distilled water five times after rinsing in $70 \%$ ethanol for $30 \mathrm{~s}$. Thereafter, the chosen leaves were placed on potato dextrose agar (PDA) plates and incubated at $25^{\circ} \mathrm{C}$ in a constant temperature unit.

\section{Identification of the pathogen}

The mycological characteristics of the colony, conidiophores, and conidia were observed under a light microscope. Amplification and sequencing of the internal transcribed spacer (ITS) rDNA and $\beta$-tubulin gene were used to identify the isolates (Kwon et al. 2012; Choudhury et al. 2014). The results of sequencing were blasted in the GenBank database. The sequences of related 
species (Alternaria solani, Aspergillus flavus, Aspergillus niger, Aspergillus ochraceus, Aspergillus sydowii, Fusarium poae) were chosen from GenBank and aligned using Clustal X 1.81 software. A phylogenetic tree was constructed with the evolutionary distance data calculated using Kimura's two-parameter model by using the neighbor-joining method with 1000 bootstrap replicates, by using DNAman software package version 5.2.2.

\section{Pathogenicity test}

The pathogenicity was tested using in vitro and in vivo wounded inoculations. The healthy leaves of field bindweed and flamed needles were used for inoculation. For the in vitro experiment, six sterilized (70\% ethanol) leaves of field bindweed were inoculated with PDA plugs $\left(78.5 \mathrm{~mm}^{2}\right)$ of each isolate of a mycelial culture, and noncolonized PDA plugs were used as controls. The petioles of the leaves were wrapped with sterilized pledget, which was soaked in sterile distilled water for $5 \mathrm{~s}$ and then placed in sterile Petri dish. For the in vivo experiment, six leaves were inoculated with the spore suspension $\left(10^{6} \mathrm{CFU} \mathrm{mL} \mathrm{mL}^{-1}\right)$, and sterile distilled water was used as the control. All the leaves and plants inoculated were placed in a plant growth chamber at $28{ }^{\circ} \mathrm{C}$ and $70 \%$ relative humidity.

\section{Results and discussion}

The symptoms of diseased leaves of field bindweed from cotton fields were observed as multiple dark brown spots (Fig. 1a), but the leaves of nearby cotton plants didn't appear to have similar symptoms. The isolates were identified as Aspergillus sp. based on their morphological identification ( $\mathrm{Lu} \mathrm{2001)}$. The colonies were white originally, which grew fast and appeared as black dots without producing pigment on the PDA 3 days later (Fig. 2d). The conidiophores were 600-3000 $\mu \mathrm{m}$ lengths and 7-21 $\mu \mathrm{m}$ widths, which grew upright, with a swollen top similar to a spherosome $(54-140 \times 60-141 \mu \mathrm{m})$, containing many oval conidia $(2.5-3.8 \mu \mathrm{m}$ in diameter) (Fig. 2e, f). The results of the gene sequences were deposited in GenBank (ITS rDNA accession no. KU195827, $\beta$-tubulin gene accession no. KU750775). The molecular identification of isolates was verified by high sequence similarity of both gene sequences of isolate strain 211 with $A$. niger (Fig. 3).

During the pathogenicity test, spots appeared rapidly on leaf surfaces and necrosis appeared on the whole leaf within three to 4 days, whereas the control did not show any symptoms (Fig. 1b, c). Some mycelium appeared on the surface of leaves inoculated in the in vitro but not the in vivo test, because the airtight conditions of the Petri dish caused the humidity in the in vitro test to be higher than that in the in vivo test (Fig. 1b). The inoculated pathogen was re-isolated and the morphology was found to be similar to that of the original isolate.

\section{Conclusions}

Based on the research results, the isolate causing diseased leaves in field bindweed was A. niger. Although a previous study of $A$. niger showed that it caused fruit rot of grapes in Xinjiang Province (Zhang et al. 2010), the metabolites showed antifungal activity and could be used to control tomato root-knot nematodes in China (Zhang 2015; Li et al. 2011). To our knowledge, this is the first report of field bindweed naturally infected with $A$. niger. In our future studies, we hope to determine host
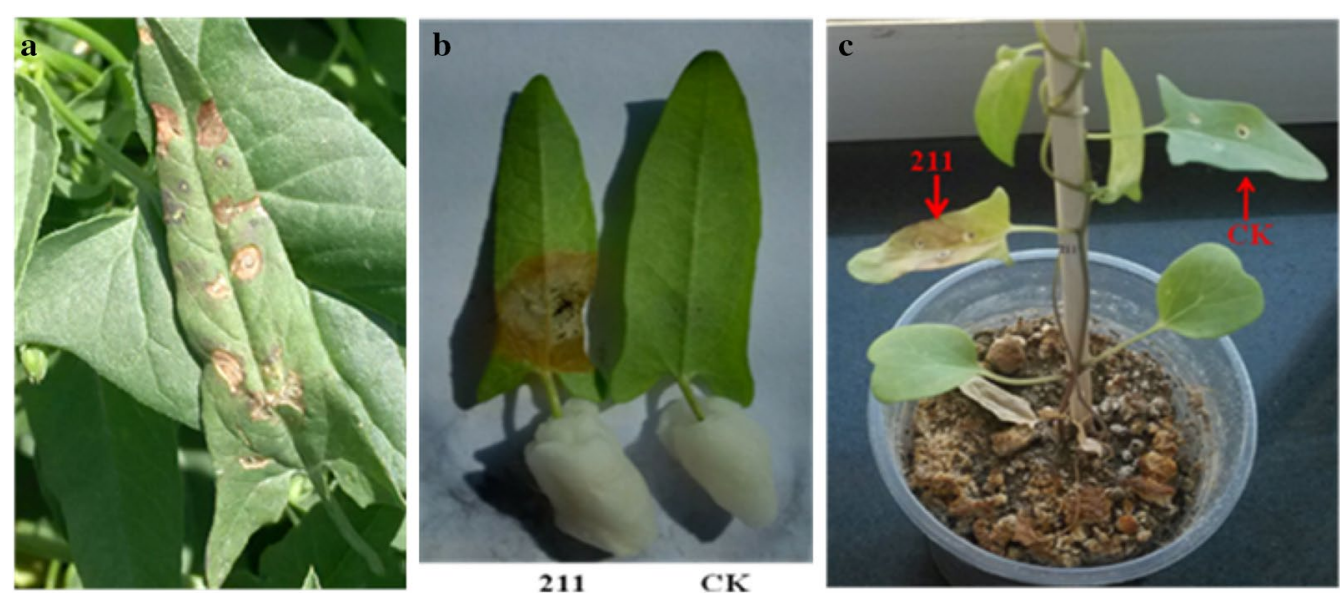

Fig. 1 Pathogenicity test to field bindweed by Aspergillus niger strain 211. a Diseased naturally leaf of field bindweed in the field; $\mathbf{b}$ wounded inoculation using strain 211 in vitro test; c wounded inoculation using strain 211 in vivo test; CK: Control 

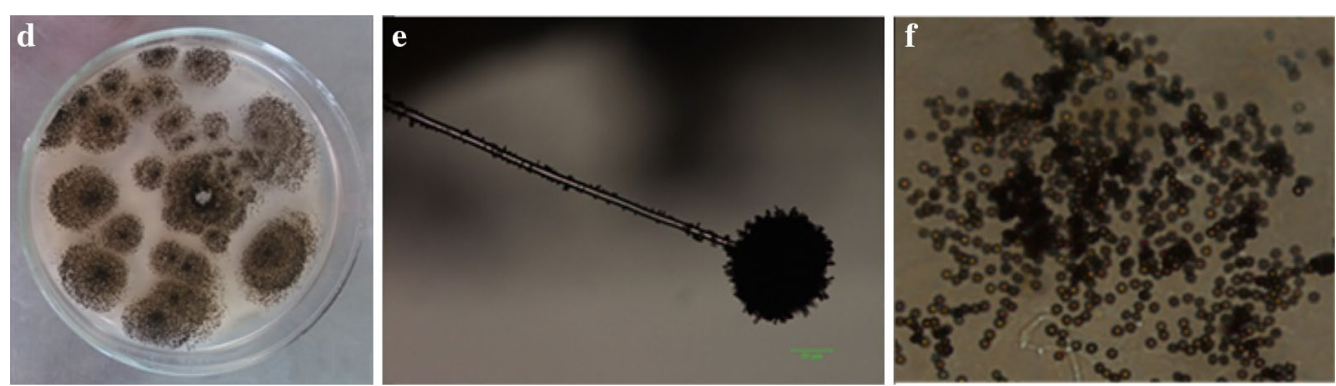

Fig. 2 Aspergillus niger morphological characteristics of colony, conidiophores and conidia. Note $\mathbf{d}$ The colony of Aspergillus niger on PDA; e Conidiophores of Aspergillus niger; $\mathbf{f}$ Conidia of Aspergillus niger

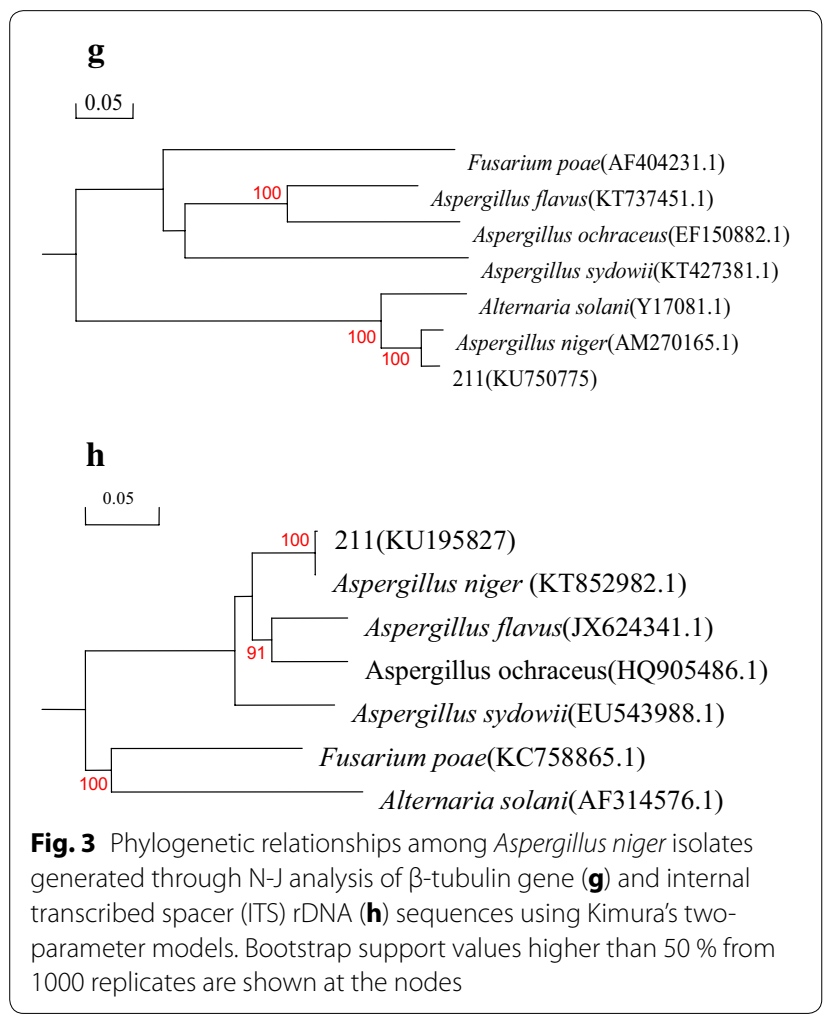

specificity and security evaluation whether $A$. niger and mycotoxins can be used as effective bioherbicides.

\section{Authors' contributions}

$X Z$ and $H X$ carried out the collection of samples and the molecular biological identification. KL and ZL assisted with molecular biological identification. YY performed the morphological identification. YS carried out pathogenicity test. JZ performed data analysis. XZ and HX drafted the manuscript. All authors read and approved the final manuscript

\section{Author details}

${ }^{1}$ Northwest Inland Region Key Laboratory of Cotton Biology and Genetic Breeding (Xinjiang), Ministry of Agriculture, Institute of Plant Protection, Xinjiang Academy Agricultural and Reclamation Sciences, No. 221 Wuyi Road,
Shihezi, China. ${ }^{2}$ Institute of Cotton, Shihezi Academy of Agricultural Sciences, Shimo Road, Shihezi, China.

\section{Acknowledgements}

This project was supported by the Xinjiang corps science and technology tackling and achievement transformation Project (No. 2015AC002).

\section{Competing interests}

All authors declare that they have no competing interests and wouldn't develop related products and apply for patent.

Received: 22 March 2016 Accepted: 5 May 2016

Published online: 12 May 2016

\section{References}

Aneja KR, Kumar V, Jiloha P, Kaur M, Sharma C, Surain P, Dhiman R, Aneja A (2013) Potential bioherbicides: Indian perspectives. In: Salar RK, Gahlawat SK, Siwach P, Duhan J (eds) Biotechnology: prospects and applications. Springer, India, pp 197-215

Charudattan R, Walker HL (1982) Biological control of weeds with plant pathogens. John Wiley, New York

Choudhury RA, Modi P, Hanstad J, Elkins R, Gubler WD (2014) First report of Diplodia seriata causing pear branch canker Dieback in California. Plant Dis 98:688

Kwon JH, Ryu JS, Chi TTP, Shen SS, Choi O (2012) Soft rot of Rhizopus oryzae as a postharvest pathogen of banana fruit in Korea. Mycobiology 40:214-216

Li S, Hartman GL, Boykin DL (2010) Aggressiveness of Phomopsis longicolla and other Phomopsis spp. on soybean. Plant Dis 94:1035-1040

Li S, Duan YX, Zhu XF, Chen LJ, Wang YY, Pan LL (2011) Effects of adding secondary metabolites of Aspergillus niger on resistance to tomato root-knot nematode. China Veg 4:44-49

Lindenmayer RB, Nissen SJ, Westra PP, Shaner DL, Brunk G (2013) Aminocyclopyrachlor absorption, translocation and metabolism in field bindweed (Convolvulus arvensis L.). Weed Sci 61:63-67

Lu JY (2001) Plant pathogenic mycology. China Agriculture Press, Beijing Ma XY, Ma Y, Peng J, Xi JP, Ma YJ, Li XF (2010) Current Situation and developing tendency of the weed researches in cotton field of China. Cotton Sci 22:372-380

Rodríguez-Navarro S, Morell HR, Alemán Martínez JA, Flores-Macías A, TorresMartínez JG (2011) Valuation of quality parameters for rearing Aceria malherbae Nuzzaci (Acari: Eriophyidae), a biological control agent of field bindweed, Convolvulus arvensis L. Int J Acarol 37:235-243

Saleem K, Arshad HMI, Babar MM (2015) First report of foliar blight of Convolvulus arvensis from Pakistan. Mycopath 13:67-69

Vasilakoglou I, Dhima K, Paschalidis K, Gatsis T, Zacharis K, Galanis M (2013) Field bindweed (Convolvulus arvensis L.) and redroot pigweed 
(Amaranthus retroflexus L.) control in potato by pre-or post-emergence applied flumioxazin and sulfosulfuron. Chil J Agric Res 73:24-30

Westwood JH, Weller SC (1997) Cellular mechanisms influence differential glyphosate sensitivity in field bindweed (Convolvulus arvensis) biotypes. Weed Sci 45:2-11
Zhang ZH (2015) Identification of fungus strain 092902 possessing antifungal activity. J Anhui Agric Sci 43:229-230

Zhang T, Meng GY, Ji LL, Liu PY, Reng YZ, Zhao BL, Wei Z, Li GY (2010) Identification of fruit rot pathogen of grape in Shihezi Region. Xinjiang Agric Sci 47:936-940
Submit your manuscript to a SpringerOpen ${ }^{\circ}$ journal and benefit from:

- Convenient online submission

- Rigorous peer review

- Immediate publication on acceptance

- Open access: articles freely available online

- High visibility within the field

- Retaining the copyright to your article

Submit your next manuscript at $\gg$ springeropen.com 